\title{
ECONOMIC PREREQUISITES OF THE FORMATION OF THE EURASIAN UNION
}

\author{
ANASTASIA LYSOKON
}

State University of Trade and Economics, Russia

\begin{abstract}
EurAsEC today is actively developing economic and political union. The purpose of this article is to review and confirmation of the objective of its formation from the point of view of economic, Anne only political preconditions. Using the method of retrospective analysis of similar economic alliances around the world, the author proves the timeliness and objectivity of EAEC as an economic and customs union, which has good prospects in view of its geopolitical situation and the level of development of its member states.
\end{abstract}

\section{JEL CLASSIFICATION \& KEYWORDS}

— J51 — EURASIAN UNION — THE CUSTOMS UNION — FINANCIAL CENTER $₫ A P E C \backsim N A F T A \backsim E U \backsim T R A N S I T$ TRAFFIC BETWEEN EUROPE AND THE PACIFIC RIM

\section{INTRODUCTION}

Today Moscow undertakes active steps in strengthening and expanding the forming Eurasian union. Creation of the united economic space in the territory of the former USSR began in 2010 with the formation of the Customs union, and has the large potential of development.

Political push to the union was given in 2011 by the publication in press of the President of Russia V.V. Putin. In the article for the "Izvestiya" newspaper, after naming the current moment historical, he opened the economic advantages of the union, its prospect and potential developmental trends.

\section{Between the West and the East - the formation Of EurAsEC}

January 1, 2012 was not only the starting point for the treaty about the customs collaboration with Kirghizia, but also the date of establishment of the united economic space in the territory of entire Customs union with the participation of its three founders. On the observation of Putin, "the project is, without exaggeration, the landmark in history not only for three our countries, but also for all states on the post-Soviet space". The latest world financial crisis gave additional push to the processes of integration, converted it from the political into the economical mechanism, necessary for further development. Common economic space will be based on the matched actions in such key institutional regions as the macro-economy, in the warranty of rules of competition, the sphere of technological regulations and agricultural subsidies, transport, tariffs of natural monopolies. Further development of the new union will make it possible to realize united visa and migratory policy, which gives the possibility to eradicate boundary control on the internal boundaries. The creative application of an experience of the Schengen Agreements, which became superior not only for Europeans themselves, but also for everyone, who arrive to work, to learn or to rest to the countries the European Union, will allow our country to become the center of the new politicoeconomic and financial association, to strengthen the positions of ruble as potential reserve currency and to economically soundly position Moscow as the new financial center of regional and potentially world scale.

As it is noted in article of V.V. Putin (1), Moscow can become the connecting link between the East and the West - "play the role of effective "bond" between Europe and dynamic
Pacific Rim". Moscow is geographically located both on the intersection of transport ways and in the time zone, from which it is convenient to work both with the European centers and with the Pacific Ocean. That is where the uniqueness of Moscow as world financial center is. Moscow is located between the Asian financial markets and the markets of Europe and USA; therefore the Moscow financial center traders can actually work twenty-four hour. This factor is essential. The absence of such possibility, time limitation became serious obstacle in the development of the financial centers of those countries, which were located in the outlying remoteness to the chief business centers of the planet and the routes of their possible interaction.

Russia at present comes out as the dominant activator of integration within the union, which emphasizes the importance of Moscow as the political center of the current processes.

In the course of the EurAsEC summit 2011 V. Putin declared beginning to realize plans of creation Eurasian union on the basis of future common economic space. And although the structure of future organization and exact plans of its creation are still not determined, wishes about the creation of the certified, visa and currency unions of the within the planned association are already spoke out.

However, two decades, which passed from disintegration of the Soviet Union, formed sovereign consciousness and tendency to maximally fence their independence in the majority of the former Soviet republics. And if for the part of them this is more a political solution, then Kazakhstan, which is the main economic and political partner of Russia in EurAsEC, has influential economic and strategic prerequisites for it. The possible solution of potential conflict can become shaping of the polypolar center of the forming union.

Kazakhstan is not agreeable to return political and economic advantage to Moscow, and successfully realizes these intentions.

Today the headquarters of EurAsEC is located both in Moscow and in Almaty, the headquarters of the Eurasian bank of development, which is actually the regional bank of development, and anticrisis fund for EurAsEC are located in Alma Ata. Thus, the substantial part of the financial resources of the new integrated association is concentrated in Kazakhstan. Undoubtedly, Russian Federation is the financial "sponsor" of the new integration, Moscow has significant historical role, but in this case for stabilization of relations and regulating financial and economic balance, and also taking the positive experience of Europe into account, it is coherent to make the distributed (net) financial center with the points of increase in Moscow and Almaty with the possibility of further distribution (for example, to Saint Petersburg).

\section{Historical experience of economic unions}

Europe has historical experience in a similar question (2). Two countries act as its economic center - Germany and France. Although the first is the undoubted economic leader (here it is possible to conduct equivalence with Russia), France is important political and administrative ally, who 
makes it possible to coordinate combined actions and to carry out the necessary economic methods of development of the European Union.

The European Union is the brightest, but far from sole example of the successful development of the economic union for the number of contiguous states.

In 1992 the North American agreement about the free trade (NAFTA) was concluded between USA, Canada and Mexico, which became the nucleus of integrated economic association. Economic integration in North America is differed from integration in Western Europe and Asia.

In other regions integration was achieved "from top to bottom", when intergovernmental agreements stimulated the contacts of the owners of different countries. In NAFTA, on the contrary, the process of integration continued "from bottom to top": first high level was reached in intercorporative connections, and then intergovermental agreements were accomplished on their basis.

NAFTA made it possible to remove barriers in trade, significantly increased possibilities for investment in the member nations of the agreement, ensured the mechanism of regulating economic disputes. In 2010 the union was enlarged after signing the packets of agreements about the free trade between USA and South Korea, Columbia, Panama. According to the estimations of experts, this extension will make it possible to create more than 280 thousand work sites, and American export will grow by 12 billion dollars (3).

Another effective union, which already exists for more than 15 years, is Mercosur - common market for the countries of South America, the economic and political agreement between Argentina, Brazil, Uruguay, Paraguay and Venezuela. Mercosur covers $55,3 \%$ of population of the countries of Latin America and Caribbean Basin, $40 \%$ of direct international investments, $33 \%$ of volume of foreign trade of the countries of the region. The joint volume of GDP of participants in the association reaches 3,3 trillion dollars. (4). Association is on the sizes and the economic potential the second customs union after the European Union and third free trading zone after the European Union and NAFTA.

However, history of both unions indicates the importance of political support at the moment of creating the association. In NAFTA USA appeared as this interested center, in Mercosure it was Brazil. The position of USA in the economic union is geographically maximally similar to the position of Russia. As USA acts as the transit state between Canada and Mexico, which cannot territorially interact directly, so Russia must become connecting link between the European part of the CIS and Central Asia.

The effective experience of existence and development of the unions indicated the possibility of development of EurAsEC for obtaining the comparable achievements. Our forming general economic space has all objective prerequisites for the integration, which testify about the historically formed moment, favorable for association of the economies of the neighboring states for creating the general politico-economic cluster, which can become the embryo of further interpenetration and consolidation of political and financial and economic space.

Today the volume of trade of participating countries of the union comprises more than 70 billion dollars (5). Russia is leading in the revolution in all pairs of countries, which confirms its leading part in this union. Naturally it is to a considerable extent explained by the scale of our country and correspondingly by the volume of its economy, but the value of territories and production complex are also the inherent factor, which forms our state, confirms our foremost positions in the development of our national currency as the regional circulating medium.

In parallel to the increased commercial revolution of the member states of EurAsEC the volumes of freight traffic between the countries of association swiftly grow. According to estimations of the experts of the integrated committee of EurAsEC, the volume of freight traffic will grow to 490 million tons by 2020 , which is almost 4 times more than the indices of 2000 . In spite of a certain forecasted retardation of increase in the goods traffics, average annual increase, according to forecast, will comprise more than $15 \%$ (6). Taking into account the leading part of Russia, our country can and must become not only the political, but also economic center of the union.

Since Russia is the objective center of the formed economic space, while the substantial part of the adjacent states has the weaker economy, further development of EurAsEC can to a considerable degree go according to the principle "of the effect of dominoes", or Peripheral Capitalism. This theory was created by Latin American economist Raul Prebish, who was not only the professor of political economy, but was also involved in practical work. According to his concept the capitalist world economy - is a single whole, in which "the center", which includes the highly developed industrial countries ("centers"), and "the periphery", which includes in essence the agricultural countries are completely clearly demarcated. In this case the outlying countries are found in the sufficiently strong economic dependence on "the centers" which prevents their development and specifies economic backwardness.

Similarly the process of association the theory of the development of economic unions is described. After the majority of countries of one or another region became the members of integrated association, the countries which remained beyond its limits unavoidably experience definite difficulties, which are connected with the reorientation of the economic relationships of the countries, which entered the group, to each other. Sometimes it also results in reduction of the volume of trade between countries, which were proven to be beyond the limits of integration. For the outsiders association with the created economic zone is the output to obtain equal rights and possibilities for its producers and exporters. As a result of increase in integration and formation of preference system for the participating countries of union, those of the states, who even do not have essential primary interest in the integration, manifest the interest in the connection to the going integration processs because of the fear to remain beyond its limits. Historically under the action of this effect it is possible to expect entry of all countries on the post-Soviet space into the created union on the base of EurAsEC.

This returns us to the publication of V.V. Putin, who indicated in his article that EurAsEC has all prospects for further effective development - not only political support of Moscow and Kazakhstan, but also commercial and transport potential. Today two poles of the economic attraction are formed on the Eurasian continent, which are already formed into powerful economic unions - these are the European Union and APEC. The first includes 17 highly developed industrial countries with the powerful economic system, developed science and technology, but poor at resources as a result of their exhaustion. Moreover a question is raised here not only about the natural resources in the form of minerals, that to a considerable degree can be compensated 
technologically, but also about the working and territorial resources. The European Union exhausted the possibility of growth of the volumes of production, it cannot place all necessary forms of industry in its territory for guaranteeing not only its needs, but also for the increase in the level of life and welfare of the country. Many transnational corporations with the political center in Europe have actually the second economy in the developing countries, where their production capacities are located.

And the given powers are mostly located in the Pacific Rim. At present APEC unites economies of 21 countries of the most different level of development. Union was based in Canberra (Australia) in 1989. Creation of APEC in 1960-1980 was preceded by prolonged development of less global economic unions in the Pacific Rim - such as ASEAN, Pacific Ocean economic council, the Pacific Ocean economic collaboration conference, South Pacific forum and others. APEC is one of the vital associations. In the middle 2000 in the countries, which form APEC there lived more than one third of world population. Here about $60 \%$ of world GDP is produced, about $50 \%$ of world trade is conducted (7). This organization became one of three (together with the European Union and NAFTA) most influential integrated blocks in contemporary world economy.

Despite the fact that APEC is the youngest of the represented three largest international economic integrated blocks it already has managed to become the important means of assistance to trade and economic collaboration in the region. APEC economic zone is the most dynamically developing on scales of planet, over the long term it can take the role of the leader of world economy in 21 century. Participating countries of APEC are very different, and for their interaction the mechanisms are formed, which are far less formalized than rules of the European Union and NAFTA.

Furthermore, special feature of APEC is the fact that this collaboration is exclusively in the economic sphere. Since the beginning of its existence APEC is considered not as the group of the countries, united politically, but as the free "totality of economies". The activity of union is developed predominantly on the basis of nonformal mechanisms, is developed broadwise and in depth. The countries of APEC could attain strong reduction in the customs taxation already in the first decade. In this case other, nontariff protectionist barriers are reduced (such as quantitative limitation on export and import, some difficulties in licensing (imported and export), export subsidies, etc). As result, the yearly rate of export increase in the APEC countries composed 4,7\% in 1995-2000; in other countries during the same period only $3,0 \%$. As a whole only in the 1990's in the APEC countries the volume of the drawn direct international investments increased 3 times, joint GNP for 1989-1999 grew by $1 / 3$ in the totality, in this case the increase composed $26 \%$ in the developed countries and $83 \%$ in the developing countries. This index is substantially higher than world-wide $(24 \%$ in the developed countries and $11 \%$ in the developing states).

Increase of foreign investments, directed to a considerable degree toward the investments to the production sphere, was provided precisely with the countries of the European Union. Accordingly, in the opposite direction the enormous goods traffic, which supplies cheaper goods because of the low cost of work force, is formed. Specifically this potential to a considerable degree can be used by EurAsEC. Strategically and territorially we become the connecting link between these two largest unions.

\section{Prospects and the potential of EurAsEC}

Today the transit potential of EurAsEC is not realized completely. According to the estimations of specialists, at present incomes from the cargo transit between Europe and Asia in 2007 comprised more than 50 billion, and with further increase in the commodity turnover by 2015 incomes can reach 80 billion. However, the absolute majority of these incomes was absorbed by sea navigable companies - $98 \%$ of transit between the Pacific Rim and Europe are transported by sea through Suez Canal (8).

I.e., transit potential at the given moment is not realized, and it is now necessary to undertake active measures so that MTK in the region would be the real source of transit incomes for the member states of EurAsEC. This is especially urgent in connection with the program of the development of Xinjiang Uyghur autonomous region called "Go West" realized in China, in the course of which a notable increase of the volumes of the production of the export goods in Xinjiang Uyghur autonomous region is expected, which gravitate towards transporting into the countries of Europe precisely on the land through the countries of EurAsEC.

In case of development of this delivery system as a result of Moscow political solutions, the ruble will obtain additional stabilizer support, it will be able to enlarge the region of its influence, to increase the turnover of funds and to reduce inflationary component. Namely this is the first sign of strengthening currency in a sufficient measure so that it could become regional pay currency.

The existing scheme of transit corridors makes it possible for EurAsEC to propose the convenient and rational ways of delivering goods to Europe from the countries of the Pacific Rim. Furthermore, the land transit way has an important competitive advantage over sea transportation "time factor". The ideal periods of load delivery from the East provinces of China and the countries of southeastern Asia to Western Europe by the railroad and automobile transport corridors through the member states of EurAsEC on the average are 2-2.5 times less than with sending loads by vessels through Suez Canal (9).

Integration of the participating countries of EurAsEC will make it possible to propose the completely advantageous conditions of a similar transport. And this "convenience" can become occasion for Russia to strengthen its financial image, to increase the volume of calculations in rubles for similar transportation. It will become the objective economic prerequisite not only of the development of EurAsEC as economic union, but also the formation of Moscow as international financial center.

Even now Moscow occupies the leading position on the accumulation of the financial tools, favorable for forming financial center here, in order to come out as the point of concentration of efforts for the development of integration processes.

Moscow is the large scientific and industrial megapolis, in which more than one third of entire scientific potential of Russia is concentrated. Moscow is the largest on an all-Russian scale financial center, international business center and control center of the large part of the economy of the country. Thus, for instance, in Moscow about half of banks from the number of those registered in Russia are concentrated. Furthermore, the large amount of the most important companies is registered and has central offices precisely in Moscow, although their production can be located for thousands of kilometers from it. 
According to the data in 2008, by the GDP volume (321 billion \$) Moscow took 15 place among the largest cities of the world (10).

The revolution of retail trade in 2007 was 2040,3 billion rub. (increase from $2006-105,1 \%$ ), the revolution of wholesale trade was, in turn, 7843,2 billion rub. (increase from 2006 $122,3 \%$ ), the volume of paid services for population - 815,85 billion. rub. (24\% of the volume of services in entire country).

According to «Ernst \& Young» data of 2011 (11), Moscow occupies the 7 th place among European cities on the investment attractiveness, moreover its rating grows, it unites migratory and financial flows.

The analysis of the development of Russian financial sector shows that Moscow on a number of the indices of the development of financial market can compete with "young" international finance centres, but at the effectiveness of the market control mechanism it loses to financial centers in the countries with the rapidly developing economy, which again indicates the need for the development of infrastructure both technical and financial. However, the need for further development always stands both for that forming and before the already formed economic associations. Accordingly, the presence of the need for modernization of part of the existing financial system indicates not the weakness of the going integration, but the separate aspects, which require correction.

\section{Conclusion}

After analyzing given data and factors, we can draw the conclusion that today there is an objectively formed possibility of the economic and political integration of Russian Federation with the states of post-Soviet space for forming the international financial center in Moscow. The countries of the CIS have already passed the part of the way of international integration, furthermore, today we observe the objective prerequisites of such rapprochement, which make it possible to make the scientifically valid conclusions about the necessity for forming international financial center in Moscow, which is historically, politically and economically positive sign moment, although it will require impulse actions on formation and development of the necessary financial - lawful base in the near future.

\section{REFERENCES}

1. Asia-Pacific Economic Cooperation. (March 5, 2012 r.). Business perspectives. Retrieved November 1, 2012 r., Of Asia-Pacific Economic Cooperation: http://www.apec.org

2. Ernst \& Young Research Centre. (2011). Investment Analysis of the capital. Retrieved November 1, 2012 r., From Ernst \& Young: http://www.ey.com/RU/RU

3. Europian Union Stat. (2011). Trade. Retrieved November 1, 2012 r., Of Europian Union: http://europa.eu/

4. Mercosur. (2011). Folleto MERCOSUR en Síntesis. Retrieved November 1, 2012 r., Of www.mercosur.int

5. The European Central Bank. (2007). How the euro became our money. A short history of the euro banknotes and coins. Retrieved November 1, 2012 r., Of The European Central Bank: http://www.ecb.int

6. U.S. International Trade Administration. (2012). Trade Statistics. Retrieved November 1, 2012 r., Of http://www.trade.gov

7. Putin, V. (October 3, 2011 r.). A new integration project for Eurasia - a future that is born today. News.

8. RIANovosti. (August 29, 2012 r.). Putin will meet with representatives of the transport community. Retrieved November 1 , 2012 r., Of Investment Guide: http://www.investgid.ru
9. Sekreatariat EurAsEC. (2011). EurAsEC today - 2011. Retrieved November 1, 2012 r., Of http://www.evrazes.com

10. Semenov, Y. (2011). The concept of addiction. Retrieved November 1, 2012 r., From the Scientific and educational magazine "Skepticism": http://scepsis.ru

11. Territorial body of the Federal State Statistics Service in Moscow. (2009). Statistics 2008. Retrieved November 1, 2012 r., Statistics from Moscow: http://www.mosstat.ru/ 